\title{
Simulation of Brushless DC Motor Speed Control with Fuzzy Logic Method
}

\author{
Ginola $^{1}$, Ali Basrah Pulungan ${ }^{2}$, Wawan Purwanto ${ }^{3}$, Ichwan Yelfianhar ${ }^{4}$ \\ ${ }^{1}$ Department of Electrical Engineering, Universitas Negeri Padang, Padang,25132, Indonesia \\ ${ }^{2}$ Department of Electrical Engineering, Universitas Negeri Padang, Padang, 25132, Indonesia \\ ${ }^{3}$ Departenent of Automotive Engineering, Universitas Negeri Padang, Padang,25132, Indonesia \\ ${ }^{4}$ Department of Electrical Engineering, Universitas Negeri Padang, Padang,25132, Indonesia \\ ${ }^{1}$ mhdginola@gmail.com
} because this type of motor has high efficiency and does not cause sparks. However, the speed control of this motor generally has a slow response to the set point, and the speed is not constant when given different loads. Therefore, it is essential to design sophisticated speed control system for this motor to improve the constant speed and speed response. This paper, the fuzzy logic method for speed control system is used to give the decision of how much voltage will be added to the motor to get to the desired speed set point value, and how much voltage will be reduced if the speed of the motor passes through the speed set point. Brushless dc motor speed is set with input voltage to the motor taking into account speed error and delta

Keywords: BLDC

Fuzzy Logic

Set point

constant

PWM speed error using Fuzzy Logic so that when the speed of the motor almost reaches the set point the input voltage to the motor is reduced so as not to overshoot until the speed of the motor reaches the set point. The results of this study gave a better response than not using fuzzy logic methods. The set point 270 gets response time to set point (Tr) faster 0.0002 seconds from 0.0046 seconds to 0.0044 , the time to steady-state (Ts) is faster 0.025 seconds from 0.04 seconds to 0.015 seconds, the maximum pass percentage $(\mathrm{Mp})$ is reducing from $75 \%$ to $20 \%$, and error speed from $1.5 \%$ to $0 \%$. The trial load at $\mathrm{t}=0.025$ seconds in set point, 270 with a load of $4 \mathrm{Nm}$ responds to the set point back for 0.014 seconds.

Copyright (C) 2020 Politeknik Aceh Selatan. All rights reserved.

\section{Introduction}

Various types of electric engines exist today, one of which is brushless direct current (BLDC) motor, which has many advantages over other types of motors [1]. The use of Brushless DC motors is widely used in robotics, health, automotive, and industrial applications to reduce air pollution produced by internal combustion engines that emit exhaust. BLDC motors have several advantages, namely high efficiency, little vibration, no sparks, little noise in high-speed usage, long service life and low maintenance costs[1][2][3][4][5].

Brushless DC motor speed control has several drawbacks, namely the response speed to the old set point and the speed that does not match the set point when charged. This problem has been studied before using various methods such as Brushless DC motor speed control with PID method and received a speed response of 0.7 seconds. This study was not tested when the BLDC motor was in load state[6], BLDC motor speed control with artificial neural network method and received a response of 0.84 seconds. This study was not tested when the BLDC motor was in load state[7], designing BLDC motor controller with fuzzy model reference learning control (FMRLC) method and getting 7.02 seconds response. There are also several other studies on BLDC motor speed control using fuzzy logic methods with function transfer models and getting a response of 0.29 seconds and this study was not tested when the BLDC motor was in load state. Other researchers 
found a 1.31-second response and the study were not tested when the BLDC motor was in a loading state.

In this study fuzzy logic method is used, where dc supply is given to each BLDC motor stator coil based on an error of BLDC motor speed. The greater the speed error, the more DC supply required. And conversely, the smaller the error speed, the less DC supply required. The test is performing through simulation based on a motor whose parameter value is close to the actual parameter value.

\section{Background}

\section{A. Brushless DC motor}

Brushless DC motor or BLDC motor is a DC motor that does not use a brush to perform commutations but uses an electrical commutation, in order to be able to rotate the BLDC motor then the stator coil of the motor must be voltage according to the sequence of the commutation, To do so then the position of the rotor must be known using the hall effect sensor or by the sensorless technique, i.e. by detecting the reverse GGL on the stator coil. At its age, the BLDC motor has three Hall Effect sensors attached near the stator and has an electronic controller in the motor to regulate the power commutation flowing in the stator coil. The role of BLDC motors here as part of which will be adjusted in speed to stabilize their rotation when the motor with load or without load.

\section{B. BLDC motor Controller}

The BLDC motor controller is an inverter that converts the voltage in the direction into alternating voltage and which regulates the power that goes into each stator coil. Brushless DC motor controllers are used to replace brushes and commutator so that BLDC motors are maintenance-free. The BLDC motor controller has two parts: the power part and the control part. The power part is the part that supplies the power to the motor stator. The control part is the part that controls the input of each phase of the motor stator [1]. The BLDC motor controller acts as a BLDC motor speed controller.

\section{Fuzzy Logic}

Fuzzy in English means a vague or obscure state. So, fuzzy logic is a logic which contains an element of uncertainty. In the usual logic, i.e. firm logic, we only know two values, false or true, 0 or 1. At the same time, fuzzy logic recognizes the value between right and wrong. The truth in fuzzy logic can be express in a degree of truth whose value is between 0 and 1. For example, in daily life, adults are defined by being 17 years of age or older. If using strict logic, a person who is 17 years old less than one day will be defined as immature. But in fuzzy logic, the person can be expressed with almost adulthood.

Fuzzy logic has several advantages, including the following.

- The concept of fuzzy logic is easy to understand. The mathematical concept underlying fuzzy logic reasoning is straightforward and easy to understand.

- Fuzzy logic is very flexible.

- Fuzzy logic has a tolerance for inappropriate data.

- Fuzzy logic is capable of modelling complex nonlinear functions.

- Fuzzy logic can build and apply the experiences of experts directly without having to go through the training process.

- Fuzzy logic can work with conventional control techniques.

- Fuzzy logic based on natural discuss

- Its usefulness is considered better than any control technique ever.

- Fuzzy controllers are renowned for their reliability.

- Easy to fix.

- Fuzzy controllers provide excellent control over other techniques. 
- The effort and funds needed are small.

The implementation of Fuzzy Logic in this design is to determine what voltage the BLDC motor controller will give to the BLDC motor to achieve the desired speed set point value. To give this decision, fuzzy logic on this design is given input error speed and delta error speed.

\section{Research Methodology}

The method applied in this study is the try and cut method, where the variables used in the input and output fuzzy logic controller are tried and deducted until they get a response that matches the ideal control characteristics. Speed response testing is performed by using simulation on MATLAB/SIMULINK with actual motor parameters and ideal control components for more precise results.

\section{A. Control Parameters}

There are several parameters as reference points to obtain appropriate BLDC motor speed control response, namely:

- The uptime (tr) is the time it takes to reach the set point, the faster, the better. But ideally less than 1 second.

- The maximum passing percentage (Mp) is the difference between the set point and the first peak value, and MP tolerance is $20 \%$.

- Steady-state (ts) is the time it takes for the response curve to reach a stable state and settle on a set point with a minimum error percentage of $5 \%$.

- Error $(\%)$ is the difference between the set point and the speed at the time ( $\mathrm{t}$ ) in the Steadystate, the error should not be more than $5 \%$.

The four parameters above are overviewed in the form of a chart below.

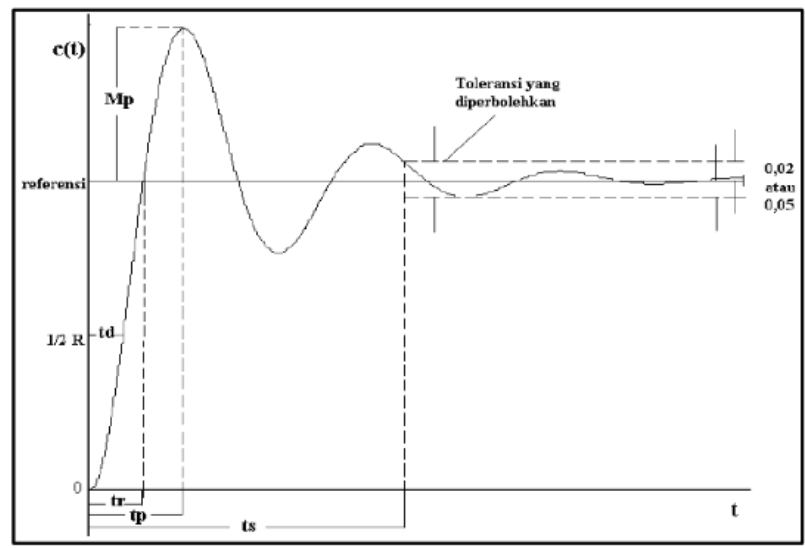

Fig. 1. Respons system

\section{B. Control Scheme}

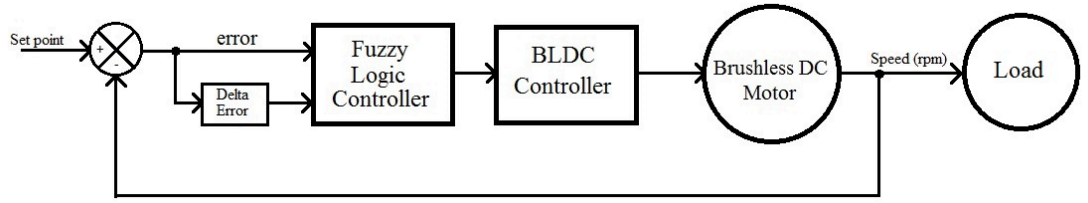

Fig. 2. Fuzzy Logic Control Scheme

Fuzzy Logic Controller (FLC) is used to control the speed of BLCD motor. Flc sets the input voltage to the BLDC motor based on the speed error or the difference between the speed and the set point. The basic concept in this design is the more significant the error speed then, the greater the voltage is added, and vice versa, the lower the error speed then, the smaller the voltage is added. 
However, this causes the Mp to exceed the $20 \%$ standard, so a delta error is entered (the difference between the error at a period $(\mathrm{t})$ and the error in the previous time (t-1)) to reduce the Mp beyond the $20 \%$ standard. The addition of delta input error causes reduced in time to reach the set point.

\section{Fuzzy logic block design}

The fuzzy logic block in Simulink Matlab is designed by changing the range and shape values of the membership functions used in input and output. The process in fuzzy logic consists of three stages, namely fuzzification, evaluation rule, and defuzzification. Fuzzification is the process of converting input values to fuzzy values. Input is split in two, namely error and delta error. The error value is the difference between the set point and the speed at the time (t). And delta error is the difference between the error at the time (t) and the error at the time (t-1). Both data are organized into their respective membership functions so that they can be used in evaluation rules. After the evaluation rule process, it is found that the output value is then converted into a value to change the output voltage through the defuzzification process.

\section{Results}

The result of this study is obtained from MATLAB/SIMULINK simulation in the form of the response time of the BLDC motor speed. The result of the experiment is compared between experiments result without fuzzy logic controllers, experiments result with fuzzy logic controllers and experiments result with fuzzy logic controllers when motors loaded at 0.025 seconds

\section{A. Experiment without Fuzzy Logic Controller}

Table 1. Speed response results without the fuzzy logic controller

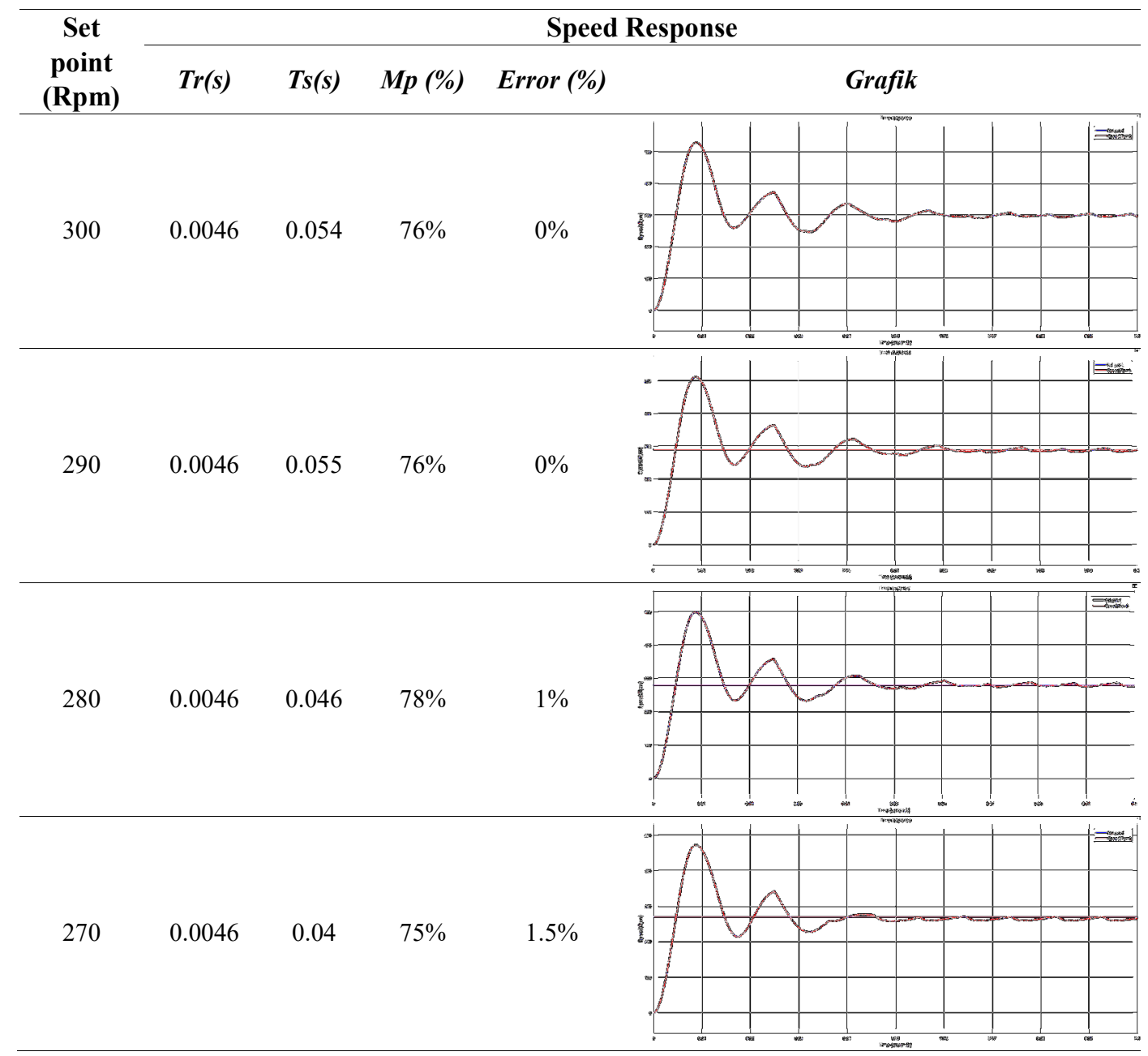


In the first experiment at the set point 270 , the response time to achieve set point $(\mathrm{Tr})$ is obtained at 0.0046 seconds, the response time to achieve steady-state (Ts) is 0.04 seconds, a maximum passing percentage (Mp) is $75 \%$, and a speed error is $1.5 \%$. The overall responses obtained by $\mathrm{Tr}$, Ts, and error are acceptable, but the Mp exceeds the ideal standard.

\section{B. Experiment with Fuzzy Logic Controller}

Table 2. Speed Response Result with Fuzzy Logic Controller

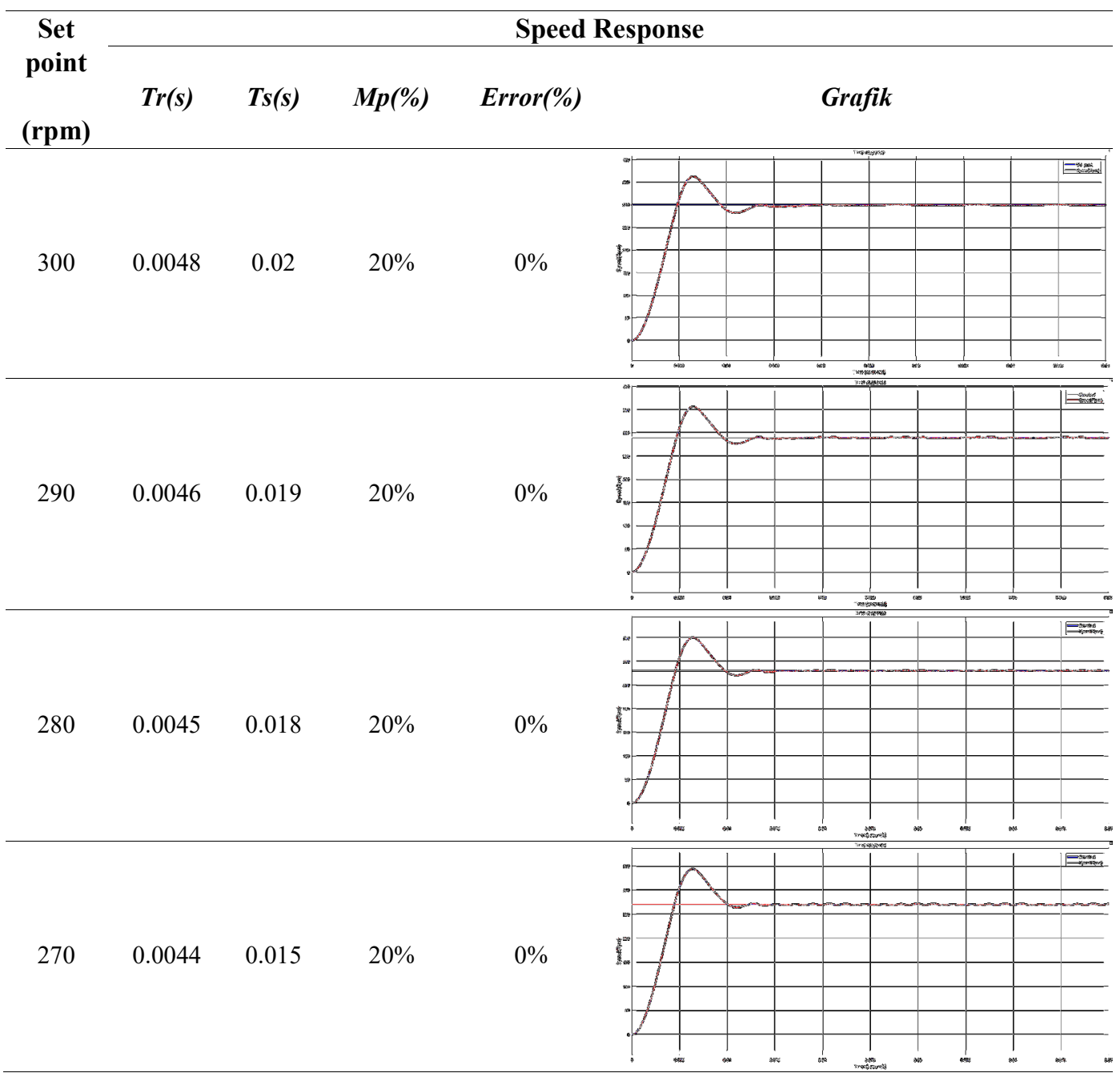

In the second experiment at the set point 270 , the response time to achieve set point ( $\mathrm{Tr}$ ) is obtained at 0.0044 seconds, time to achieve a steady-state (Ts) is 0.015 seconds, maximum passing percentage (Mp) is $20 \%$, and speed error is $0 \%$. From these results, a slightly better response than the first experiment is shown a reduction from 0.0046 seconds to 0.0044 seconds. Ts on the second experiment had a much faster response than the first simulation which is 0.04 seconds to 0.015 seconds in order, error speed is decreased from 1.5 to $0 \%$, and $\mathrm{Mp}$ from $75 \%$ to $20 \%$. 
C. Experiment with Fuzzy LogicController when Motor loaded at 0.025 seconds

Table 3. Speed Response Test Results with Fuzzy Logic Controller when Motor Loaded at 0.025 Seconds

\begin{tabular}{|c|c|c|c|c|c|c|c|c|c|c|c|c|c|}
\hline $\begin{array}{l}\text { Load } \\
(\mathrm{Nm})\end{array}$ & $\begin{array}{l}\text { Max } \\
\text { error }\end{array}$ & $\begin{array}{l}\text { Min } \\
\text { error }\end{array}$ & Time error & Error \% & & & & Grc & fik & & & & \\
\hline & & & & & & & & & 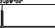 & & & & 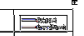 \\
\hline & & & & & & & & & & & & & 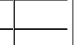 \\
\hline & & & & & & & & & & & & 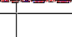 & 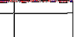 \\
\hline 1 & 271 & 265 & $0.025-0.029$ & $0 \%$ & & & & & & & & & \\
\hline & & & & & & & & & & & & & \\
\hline & & & & & & 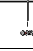 & & : & 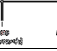 & $l_{a s}$ & 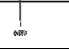 & $!$ & 1 \\
\hline & & & & & & $\|$ & & 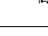 & 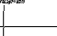 & I & 1 & 1 & $\mid=-5=0$ \\
\hline & & & & & & & $=$ & $-\infty=$ & 5 & 1 & 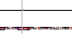 & 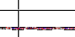 & $\frac{1}{1}$ \\
\hline & & & & & & & & & & & & & \\
\hline 2 & 270 & 258 & $0.025-0.031$ & $0 \%$ & & & & & & & & & \\
\hline & & & & & & & & & & & & & \\
\hline & & & & & & & & & & & & & \\
\hline & & & & & & & & & tom & & $\frac{1}{\infty}$ & 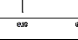 & $\frac{1}{x+5}$ \\
\hline & & & & & & & & & sime & & + & L & $l=2=$ \\
\hline & & & & & & & & & & & & & \\
\hline & & & & & & & & 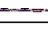 & 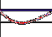 & $=$ & {[} & 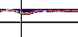 & $+\infty$ \\
\hline 3 & 270 & 248.5 & $0.025-0.03$ & $1 \%$ & & & & & & & & & \\
\hline & & & & & & & & & & & & & \\
\hline & & & & & & & & & & & & & \\
\hline & & & & & & & & & 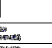 & & 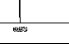 & & 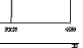 \\
\hline & & & & & & & & & wer & & & 1 & 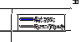 \\
\hline & & & & & & & & & & & & & \\
\hline & & & & & & $-\infty$ & - & 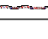 & $\Rightarrow$ & $=$ & $=$ & $+\infty$ & $\Longrightarrow$ \\
\hline 4 & 269 & 236.5 & $0.025-0.039$ & $2 \%$ & & & & & & & & & \\
\hline & & & & & & & & & & & & & \\
\hline & & & & & & & & & & & & & \\
\hline & & & & & & & & . & $=$ & 1 & $\ldots$ & 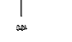 & 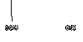 \\
\hline
\end{tabular}

In the last experiment, the response of the motor when loaded at $t=0.025$ seconds is shown. The result shows that the speed returned to the set point is achieved at 0.025 seconds to 0.031 seconds, with error equal to zero percent.

\section{Conclusion}

From the results of the study, it can be concluded that fuzzy logic controller control BLDC motor is able to provide better system response than those that do not use fuzzy logic controller and stabilization when the load is given also shows a tangent response in load conditions. Where set point 270, response time to set point (Tr) observed faster 0.0002 seconds from 0.0046 seconds to 0.0044 , the time to steady-state (Ts) is faster 0.025 seconds from 0.04 seconds to 0.015 seconds, the maximum pass percentage (Mp) is reduced from $75 \%$ to $20 \%$, and error speed from $1.5 \%$ to $0 \%$. Lastly, for a loading experiment at $\mathrm{t}=0.025$ seconds in set point, 270 with an amount load of $4 \mathrm{Nm}$ response returned to the set point for 0.014 seconds.

\section{References}

[1] M. Dewangga, "Desain Sistem Kontrol kecepatan Motor BLDC Berbasis Programmable Array Logic Dengan Metode Six Step Commutation," 2015.

[2] R. Randis and S. Akbar, "Rancang Bangun Alat Ukur Gaya Dorong Dan Kecepatan Putaran Motor Brushless," Din. J. Ilm. Tek. Mesin, vol. 9, no. 2, 2018. 
[3] A. P. Nandiwardhana, H. Suryoatmojo, and M. Ashari, "Perancangan Zeta Converter yang dilengkapi Power Factor Correction pada Aplikasi Pengaturan Kecepatan Motor Brushless DC," J. Tek. ITS, vol. 5, no. 2, 2016, doi: 10.12962/j23373539.v5i2.16099.

[4] H. P. Putra, H. Suryoatmojo, and S. Anam, "Perbaikan Faktor Daya Menggunakan Cuk Converter pada Pengaturan Kecepatan Motor Brushless DC," J. Tek. ITS, vol. 5, no. 2, 2016, doi: 10.12962/j23373539.v5i2.16097.

[5] A. B. Pulungan, Sukardi, and T. Ramadhani, "Buck Converter Sebagai Regulator Aliran Daya Pada Pengereman Regeneratif," J. EECCIS, vol. 12, pp. 93-97, 2018.

[6] T. K. Priyambodo, "Implementasi Sistem Kendali PID pada Gimbal Kamera 2-sumbu dengan Aktuator Motor Brushless,” IJEIS (Indonesian J. Electron. Instrum. Syst., vol. 7, no. 2, p. 111, 2017, doi: $10.22146 /$ ijeis. 18238 .

[7] L. Widaningrum, B. Setiyono, and M. A. Riyadi, "Perancangan Kontroler Jaringan Syaraf Tiruan BSpline Berbasis Mikrokontroler Atmega16 Sebagai Kendali Kecepatan Motor Brushless Dc (BLDC)," Transient, vol. 6, no. 3, p. 373, 2017, doi: 10.14710/transient.6.3.373-379.

[8] M. R. Fajrianto, "PERANCANGAN KONTROLER FUZZY MODEL REFERENCE LEARNING CONTROL ( FMRLC ) BERBASIS MIKROKONTROLER ATMEGA16 SEBAGAI KENDALI MOTOR BRUSHLESS DC ( BLDC ) Metode."

[9] A. D. Yulianta, S. P. Hadi, and Suharyanto, "Pengendalian Kecepatan Motor Brushless dc Menggunakan Metode Logika Fuzzy," J. Sains, Teknol. dan Ind., vol. 8, no. 1, pp. 1-9, 2015, doi: $10.1007 / \mathrm{s} 00221-005-2275-0$.

[10] R. Dwirahayu and B. Setiyono, "Perancangan Kontroler Logika Fuzzy Berbasis Mikrokontroler Atmega32 Sebagai Kendali Kecepatan Motor Brushless Dc ( BLDC ),” no. Dc, pp. 108-114, 2016.

[11] E. S. Puspita and L. Yulianti, "Perancangan sistem peramalam cuaca berbasis Logika Fuzzy," Media Infotama, vol. 12, no. 1, pp. 1-10, 2016. 